\title{
ESTIMATION OF PROTEIN PRECIPITATION IN PULSES BY DIFFERENT SALT GRADIENTS, USING AMMONIUM SULFATE
}

\author{
PRATEEK TRIPATHI $^{\mathrm{a} 1}$, ARITRI NATH ${ }^{\mathrm{b}}$ AND INDUJA DIXIT ${ }^{\mathrm{c}}$ \\ ${ }^{\mathrm{ab}}$ KIIT School of Biotechnology, Kalinga Institute of Industrial Technology (KIIT), Odisha, Bhubaneswar, India \\ ${ }^{\mathrm{c}}$ Department of Clinical and Therapeutic Nutrition, Charak Hospital and Research Centre, Dubagga, Lucknow, U.P., India
}

\begin{abstract}
The percent saturation of salt was obtained from six different varieties of pulses namely, Black Gram, Rajma, Toor, Horse Gram, Mung Beans, and Masoor using Ammonium sulfate gradient precipitation to estimate the amount of protein content in these pulses. The salt saturation of $50 \%$ and $70 \%$ provided the maximum isolation of total protein, while $10 \%$ and $70 \%$ salt saturation provided the highest isolation in the case of soluble proteins. Our data showed that orange lentils have maximum protein concentration both in terms of total protein as well as soluble proteins. In summary, ammonium sulfate gradient precipitation method can be used as an economical way to isolate proteins with least processing involved.
\end{abstract}

KEYWORDS: Pulse Proteins, Lentils, Ammonium Sulfate Precipitation, Lowry Assay

Pulses (Peas, Lentils, Beans) contribute a major portion of protein in a vegetarian diet and the only source of protein for a vegan. Pulses have approximately $20-25 \%$ protein. This protein is bound and difficult to access that is the reason that the bioavailability of this protein chunk is mostly not that optimum. Pulses also lack an essential amino acid, methionine but this deficiency can be fulfilled by combining cereals with pulses. (IngerBjörck, 2000) (Hatford, 1985)

Pulses have high carbohydrate content. A large population of pulses stores it as starch, approximately $50 \%$, and $1.8-18 \%$ comes from oligosaccharides with dietary fibers contributing to $4.3-25 \%$ in their seed coat or skin (Ofuya and Akhidue, 2005). These dietary fibers limit the absorption of carbohydrates and slow down digestion leading to agradual increase in the blood sugar, as well as cholesterol levels (Shridhar K. Sathe, 1984) (Burkitt and Trowell, 1985). The energy provided by the pulses comes around $300 \mathrm{Kcal} / 100 \mathrm{gm}$. (Ofuya and Akhidue, 2005)

Pulses are also a source of vitamins like thiamine, pyridoxine, folic acid and riboflavin, Vitamin $\mathrm{E}$ and $\mathrm{K}$ are also found in pulses (Ofuya and Akhidue, 2005). The vitamins are present inside the body of pulses so there is no loss of these essential micronutrients while removing the seed coat.

The current study is based on estimating the amount of protein that can be isolated from pulses using gradient precipitation.
The amount of protein isolated at different salt gradients can provide a better understanding of the bioavailability and prospects of pulses protein isolation as a product.

\section{MATERIALS AND METHODS}

A total of six pulses namely, Biri (Black Gram), Rajma (Red Kidney Beans), Toor (Yellow Lentils), Kolatha (Horse Gram), Mung (Mung Beans), and Masoor (Orange Lentils) were used for total protein isolation. Seeds were obtained from the 24 Mantra Organic (India). The reagents used were analytical grade obtained from SRL (India), Hi Media (France), MP Biomedicals (USA) and MERCK specialties Private Limited (USA). The facilities of KIIT School of Biotechnology were used for performing the experimental protocols.

\section{Protein Isolation}

For protein isolation, the six selected pulses were divided into two groups. Group 1- Total Protein, Group 2Soluble protein extraction.

\section{Ammonium sulfate Gradient precipitation}

Total proteins were precipitated from pulses using Ammonium sulfate gradient precipitation method. In this method the Ammonium sulfate concentration increases in a stepwise manner, and the precipitated protein is recovered at each stage. Each protein precipitate is dissolved into a fresh buffer and assayed for total protein content.

The gradients selected for this experiment were based on the values described by (Hughes, 1955). The

${ }^{1}$ Corresponding author 
selected percentages were $10 \%, 30 \%, 50 \%$ and $70 \%$ which were calculated as per the volume of extract present $(40 \mathrm{ml})$.

\section{Sample Preparation And Total Protein Isolation}

Seeds of the six pulses were grounded individually in a clean grinder and stored at $4^{0} \mathrm{C}$ for further processing. Total proteins were isolated by macerating the powdered pulse samples in PBS (1X) and centrifuge at 3000rpm.

The supernatant obtained was added to a new testtube and calculated amount of salt as per $10 \%$ saturation was added. The precipitate was again macerated in PBS. This process was repeated three times to ensure maximum extraction of protein in the PBS buffer. The complete process was carried at $4^{\circ} \mathrm{C}$ to prevent denaturation or damage to isolated protein samples.

Ammonium sulfate was completely dissolved in the supernatant and again subjected to centrifugation at $4^{0} \mathrm{C}$. The final precipitate recovered was the isolated protein at $10 \%$ salt saturation. Similarly, the other three percent salt saturation, $30 \%, 50 \%$ and $70 \%$ was added and processed was repeated for total protein isolation at therespective gradient. All isolated samples were stored in $1 \mathrm{ml}$ of $(1 \mathrm{X})$ PBS at $4^{\circ} \mathrm{C}$ for further analysis.

\section{Isolation of Soluble Proteins}

\section{Sample Preparation and Soluble Protein Isolation}

The dried pulses were soaked for $24 \mathrm{hrs}$ in distilled water in the ratio of 1:2 (Pulse: water) and the water was collected and stored for protein isolation.

The collected soluble protein samples were directly subjected to gradient salt precipitation and the protein precipitate at various gradients was stored in $1 \mathrm{ml}$ of (1X) PBS at $4^{0} \mathrm{C}$ for further analysis.

\section{Quantification of Protein Using Lowry Assay}

Lowry Assay was used to quantitatively determine protein precipitation as described by (Oliver H. Lowry, 1951). Each sample was taken in triplicates and with appropriate dilution which was later extrapolated. The concentration of isolated proteins was calculated using standard BSA curve generated parallel to the experiment.

\section{Statistical Analysis}

Results were analyzed using one way ANOVA to find the significance of the values and were expressed using bar graphs with standard deviation and mean.

\section{RESULTS}

\section{Total Protein}

The Total Protein obtained from gradient precipitation, followed by estimation of protein concentration by Lowry assay was conducted. The results depicted that the salt concentrations of $50 \%$ and $70 \%$ were the most suitable ammonium sulfate gradients to obtain maximum protein isolation.

The maximum total protein isolation was found in Orange Lentils, giving a concentration of $5.016 \mathrm{mg} / \mathrm{ml}$, at $50 \%$ salt concentration. The least concentration of protein was found in Horse Gram, $0.086 \mathrm{mg} / \mathrm{ml}$ at $30 \%$ salt concentration. The complete data of total proteins obtained at different salt saturation levels is given in Table 1.

The protein isolated individually at different salt saturation gradients are provided in figure 1. The grouped mean found out by one way ANOVA is provided in figure 2 depicting the salt saturation that is best suited for total protein isolation from pulses.

Table 1: Concentration of total proteins isolated at different salt saturation levels of Ammonium sulfate

\begin{tabular}{|c|c|c|c|c|c|c|}
\hline \multicolumn{7}{|c|}{ Protein Concentration (mg/ml) } \\
\hline $\begin{array}{c}\text { Salt } \\
\begin{array}{c}\text { Saturation } \\
\left(\mathbf{N H}_{\mathbf{4}} \mathbf{~} \mathbf{2}_{\mathbf{4}}\right.\end{array}\end{array}$ & $\begin{array}{c}\text { Masoor } \\
\text { (Orange } \\
\text { Lentils) }\end{array}$ & Mung Beans & $\begin{array}{c}\text { Biri (Black } \\
\text { Gram) }\end{array}$ & $\begin{array}{c}\text { Toor (Yellow } \\
\text { Lentils) }\end{array}$ & $\begin{array}{c}\text { Rajma (Red } \\
\text { Kidney Beans) }\end{array}$ & $\begin{array}{c}\text { Local } \\
\text { (Horse Gram) }\end{array}$ \\
\hline $10 \%$ & 0.702 & 0.817 & 1.206 & 0.216 & 0.891 & 0.254 \\
\hline $30 \%$ & 1.304 & 2.298 & 0.967 & 0.458 & 0.657 & 0.086 \\
\hline $50 \%$ & 5.016 & 2.824 & 1.286 & 2.868 & 3.241 & 0.984 \\
\hline $70 \%$ & 1.202 & 2.868 & 0.413 & 0.760 & 2.722 & 0.525 \\
\hline
\end{tabular}




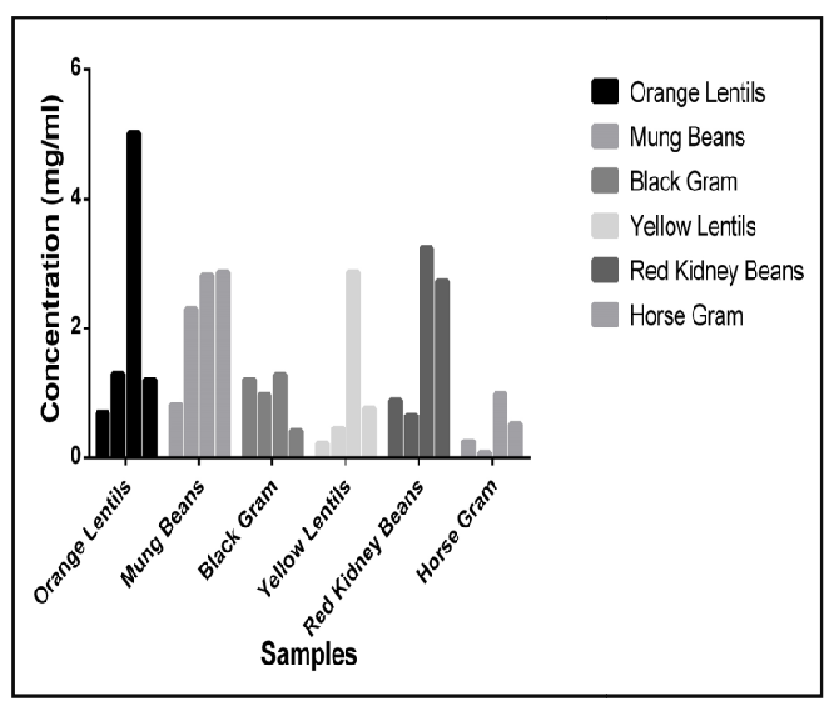

Figure 1: Represents the different samples and their respective protein concentration that have been isolated using the Ammonium sulfate salt gradient of $10 \%, 30 \%$, $\mathbf{5 0 \%}$ and $\mathbf{7 0 \%}$ respectively. It was observed that the salt concentration of $50 \%$ and $70 \%$ have provided the maximum amount protein precipitation

\section{Soluble Protein}

The soluble protein isolated from different pulses and legume samples were estimated by Lowry assay and it was observed that the protein isolation in the $10 \%$ salt saturation by Ammonium sulfate gave the highest protein isolation. The salt concentration of $70 \%$ also gave ahigh level of protein isolate concentration.

The salt concentration of $30 \%$ and $50 \%$ gave a low protein isolation as was evident from the figure 3 . Figure 4

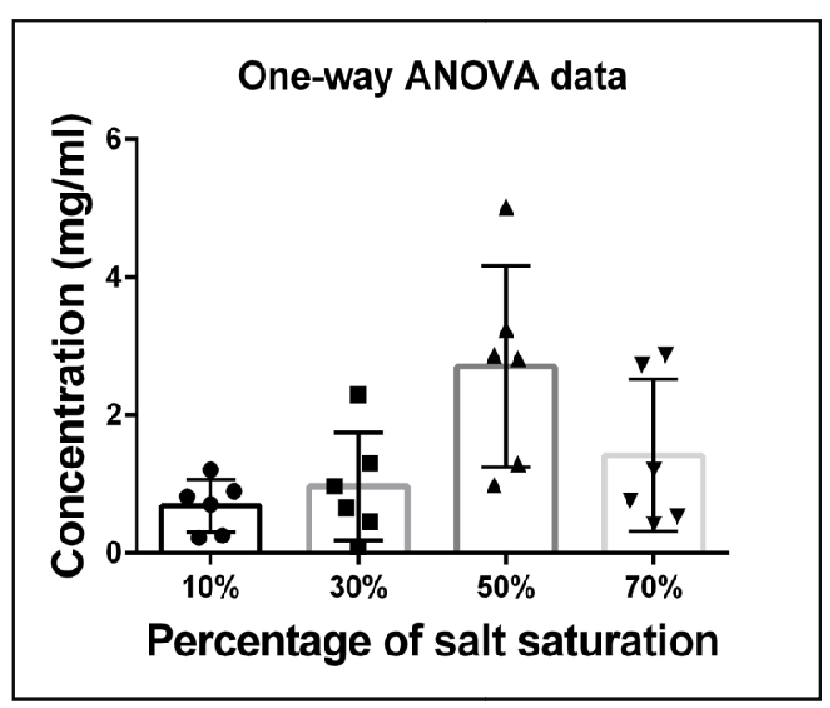

Figure 2: Representation of total protein isolated at $10 \%, 30 \%, 50 \%$ and $70 \%$ salt saturation. One way ANOVA performed with significant group mean values $(P<0.05)$. The data suggests that a high amount of protein isolation was obtained at $\mathbf{5 0 \%}$ salt saturation level. Masoor (Orange Lentils) had a concentration of $5.016 \mathrm{mg} / \mathrm{ml}$ at $50 \%$ salt saturation, which was the highest for any of the samples tested

depicts the mean of soluble proteins obtained by one way ANOVA method to confirm the best salt saturation level for the isolation of soluble proteins from pulses.

The maximum protein concentration was isolated from Orange lentils i.e. $5.039 \mathrm{mg} / \mathrm{ml}$ at $10 \%$ salt gradient, with the least concentration of $0.142 \mathrm{mg} / \mathrm{ml}$ of Horse Gram at $50 \%$ salt gradient. The complete data for the soluble proteins precipitated at different salt saturation levels is provided in Table 2 .

Table 2: Concentration of protein isolated from soluble proteins with different salt saturation levels of Ammonium sulfate

\begin{tabular}{|c|c|c|c|c|c|c|}
\hline \multicolumn{9}{|c|}{ Protein Concentration (mg/ml) } \\
\hline $\begin{array}{c}\text { Salt } \\
\begin{array}{c}\text { Saturation } \\
\left(\mathbf{N H}_{\mathbf{4}} \mathbf{~} \mathbf{2}_{\mathbf{S O}}\right.\end{array}\end{array}$ & $\begin{array}{c}\text { Masoor } \\
\text { (Orange } \\
\text { Lentils) }\end{array}$ & Mung Beans & $\begin{array}{c}\text { Biri } \\
\text { (Black } \\
\text { Gram) }\end{array}$ & $\begin{array}{c}\text { Toor } \\
\text { (Yellow } \\
\text { Lentils) }\end{array}$ & $\begin{array}{c}\text { Rajma } \\
\text { (Red Kidney } \\
\text { Beans) }\end{array}$ & $\begin{array}{c}\text { Local } \\
\text { (Horse Gram) }\end{array}$ \\
\hline $10 \%$ & 0.5039 & 1.453 & 0.915 & 4.451 & 1.714 & 1.470 \\
\hline $30 \%$ & 0.288 & 0.324 & 0.236 & 1.516 & 0.800 & 0.305 \\
\hline $50 \%$ & 0.966 & 0.712 & 0.712 & 2.957 & 2.032 & 0.142 \\
\hline $70 \%$ & 1.124 & 1.958 & 1.491 & 2.907 & 2.086 & 0.630 \\
\hline
\end{tabular}




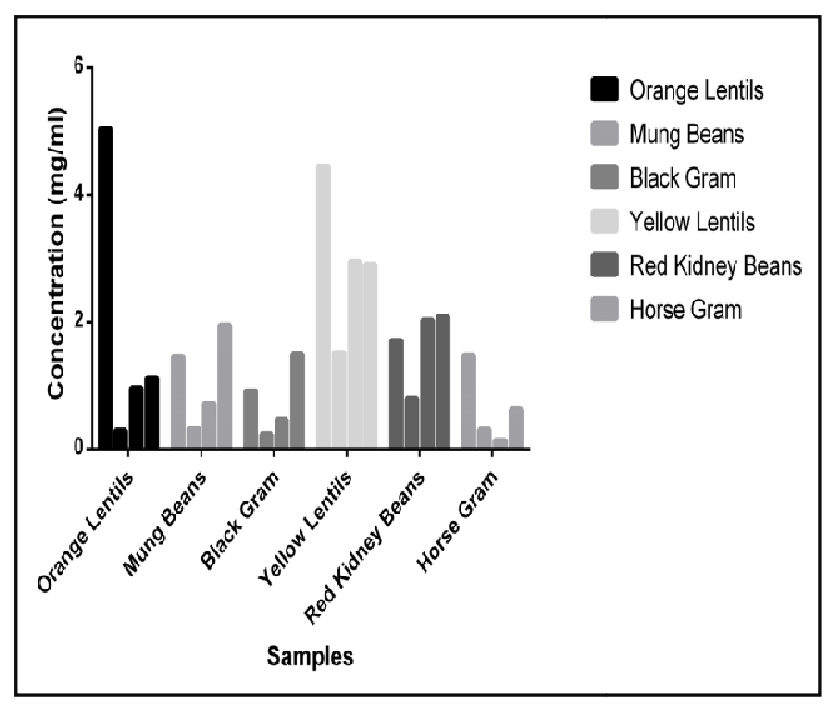

Figure 3: The graphical representation depicting the concentration of proteins isolated at different percentages of salt saturation. As it is evident from the figure, the saturation percentage of $10 \%$ and $70 \%$ of salt gave a high level of protein isolation as compared to $30 \%$ and $50 \%$ of salt saturation

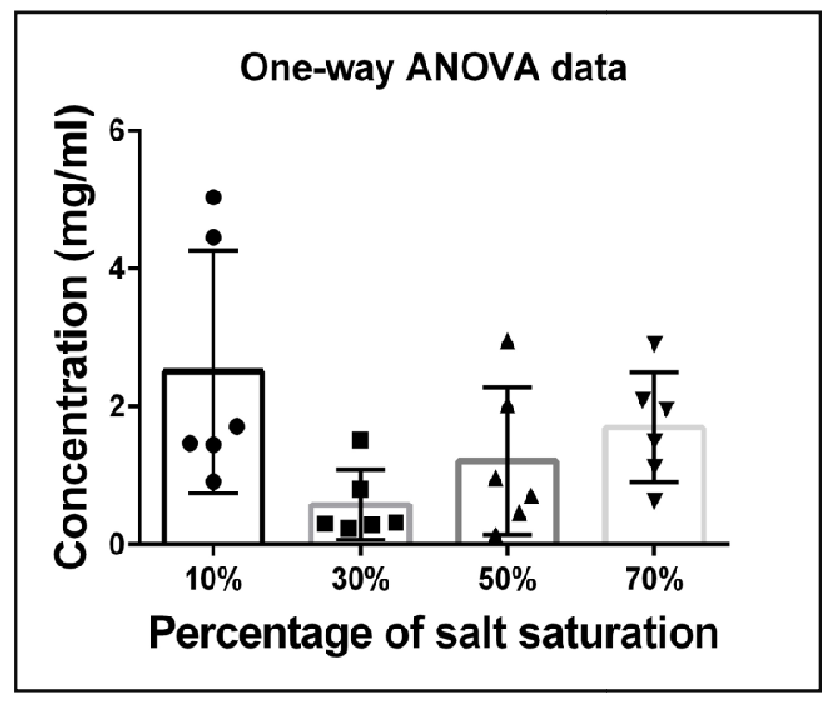

Figure 4: The graph represents the soluble protein isolated at salt saturation levels of $10 \%, 30 \%, 50 \%$ and $70 \%$. One way ANOVA result concludes the mean of the grouped data not to be significant. Masoor (Orange Lentils) and Toor (Yellow Lentils) had the highest protein isolation of $5.039 \mathrm{mg} / \mathrm{ml}$ and $4.451 \mathrm{mg} / \mathrm{ml}$ respectively at $10 \%$ salt saturation

\section{DISCUSSION}

Pulses consist of a large amount of proteins as we found out from our study, the characteristics of pulses proteins were described by (Joyce Boye, 2010), according to them, proteins present in asignificantly large amount in pulses, are globulins and albumins. Albumins are water soluble and consist of enzymes like, protease inhibitors, amylase inhibitors and lectins, their molecular mass ranges from $5 \mathrm{KDa}$ to $80 \mathrm{KDa}$. Globulins are salt-soluble proteins, two major globulins are found in pulses, which are legumin and vicilin. Pulse proteins are high in lysine, leucine, aspartic acid glutamic acid and arginine, But lack methionine, cysteine and tryptophan (Swanson, 1990).

The protein digestibility percentage of lentils and mung beans were found to be 79.1 and 68.54 according to (In Hwa Han, 2007 and El-Moniem, 1999) respectively. These digestibility percentages were found after treatment of pulses under boiling conditions.

According to our results, lentils have provided us with the highest amount of protein content per $\mathrm{ml}$ of sample. So if the protein digestibility is lesser than other highly processed isolates, it can still be used as a more economical protein source for the masses.

Protein Isolates made from orange lentils can be most effective for consumption and can be isolated with least processing as the salt gradient method is a very well know an effective method for easy isolation of these pulse proteins.

\section{ACKNOWLEDGEMENT}

This research was supported by Food Technology Laboratory, KIIT School of Biotechnology. I would like to thank KIIT School of Biotechnology for the facilities and chemical reagents provided for the experiments.

We thank Dr. Gargi Dey, Associate Professor, KIIT School of Biotechnology, for her mentorship and constant support throughout the project and Ms. Srijita Sireswar, Ph.D scholar at KIIT School of Biotechnology for assistance with standardization methods and experimental techniques.

\section{REFERENCES}

Burkitt D. and Trowell H., 1985. Refined carbohydrates in foods and disease. Academic Press New York. 
TRIPATHI ET AL.: ESTIMATION OF PROTEIN PRECIPITATION IN PULSES BY DIFFERENT SALT GRADIENTS...

El-Moniem G.A., 1999. Sensory evaluation and In vitro protein digestibility of mung bean as affected by cooking time. Journal of the Science of food and agriculture, 2025-2028.

Hatford P., 1985. The family nutritional workbook. Thorson's Publishing Group.

Hughes A.A., 1955. Protein Fractionation on the Basis of Solubility in Aqueous Solutions of Salts and Organic Solvents. Methods in Enzymology, 67 90.

In Hwa Han, B. G.-K., 2007. Protein Digestibility of Selected Legumes Treated with Ultrasound and High Hydrostatic Pressure During Soaking. Cereal Chemistry, 518-521.

Inger Bjorck H.L., 2000. Low glycaemic - index foods. British Journal of Nutrition.

Joyce Boye F.Z., 2010. PUlse Proteins: Processing, Characterization, Functional Properties and applications in food and feed. Food Research International, 414-431.

Ofuya Z.M. and Akhidue V., 2005. The Role of pulses in Human Nutrition: A Review. Journal of Applied Science and Environmental Management, 99-104.

Oliver H. and Lowry N.J., 1951. Protein Measurement with the Folin Phenol Reagent. The Journal of Biological Chemistry.

Shridhar K. and Sathe S.D., 1984. Dry beans of Phaseolus. A Review. Part 2. Chemical composition: Carbohydrates, Fiber, minerals, vitamins, and lipids. CRC Critical Reviews in Food Science and Nutrition, 41-93.

Swanson B.G., 1990. Pea and Lentil Protein Extraction and Functionality. Journal of the American Oil Chemists Society, 276-280. 